\title{
PATHOLOGICAL AND STRUCTURAL ASSESSMENT OF A RESIDENTIAL BUILDING IN LOTA, CHILE M. CHÁVEZ ${ }^{*}$, F. MACAYA ${ }^{2}$, E. NÚÑEZ ${ }^{3}$ AND C. OYARZO ${ }^{4}$
}

\author{
${ }^{1}$ Department of Civil Engineering, Universidad Andres Bello, 4300866 Concepción, Chile; \\ manuel.chavez@unab.cl(*corresponding author) \\ ${ }^{2}$ Civil Engineer, Universidad Andres Bello, 4300866 Concepción, Chile; \\ f.macayapalma@uandresbello.edu \\ ${ }^{3}$ Department of Civil Engineering, Universidad Católica de la Santísima Concepción, 4090541 \\ Concepción, Chile; enunez@ucsc.cl \\ ${ }^{4}$ Department of Civil Engineering, Universidad Católica de la Santísima Concepción, 4090541 \\ Concepción, Chile; coyarzov@ucsc.cl
}

Keywords: Concrete Pathologies, Structural Assessment.

\begin{abstract}
.
The urban development of Lota city (Chile) was strongly influenced by the coal-mining industry during 19th and 20th century. Virtually, the entire city was built, initially, by Matias Cousiño's Coal Company and, later, by the National Coal Company of Chile (ENACAR). At the beginning of the 21st century, the city began to experience a decline because of the closure of coal mines. This situation affected not only the economy and employment of the city, but also the maintenance of its infrastructure and the conservation of historical buildings.

The "Anibal Pinto Building" is a 5 stories reinforced concrete and masonry structure, built in 1966. Besides of an aggressive coastal environment and poor maintenance, this building has experienced one major earthquake (Mw 8.8 in 2010). As a consequence, cracks, concrete spalding and reinforcement corrosion is observed in several structural elements.

To evaluate the current state of the building and determine it remaining operation life, a structural assessment procedure was implemented based on field explorations, laboratory analysis and numerical modeling. Field explorations considered tests to identify carbonation, humidity, porosity, concrete hardness. While, laboratory analysis included compression test of concrete cores extracted from the building. These investigations were developed with the aim of determine the mechanical properties of buildings materials and for identifying pathologies that affects reinforced concrete.

The experimental data was used to elaborate a finite element model in SAP 2000 to estimate building performance compared to the current seismic regulation in Chile.
\end{abstract}




\section{INTRODUCTION}

Natural events, such as earthquakes, floods, fires and climate conditions, affect the structural performance of buildings. The accumulated effect of these events may progressively deteriorate the structure, becoming a pathology that needs to be treated to restore structural safety and serviceability to buildings [1-4]. The analysis of pathologies on reinforced concrete structures aims to detect and quantify accumulated damage to provide information to make decision regarding to repairing, retrofitting or demolishing the structure [5-7]. The most common pathologies on reinforced concrete structures are oxidation and corrosion of rebars, concrete spalding and carbonation, cracking, settlement and creep, in addition to problem related to design and construction errors or geometry alterations [8-10].

The research presented here corresponds to a pathological and structural assessment of the "Anibal Pinto Block", located in Lota, Chile. Lota's urban development was strongly influenced by the coal-mining industry during $19^{\text {th }}$ and $20^{\text {th }}$ century. Virtually, the entire city was built, initially, by Matias Cousiño's Coal Company and, later, by the National Coal Company of Chile (ENACAR). At the beginning of the $21^{\text {st }}$ century, the city began to experience a decline because of the closure of coal mines. This situation affected not only the economy and employment of the city, but also the maintenance of its infrastructure and the conservation of historical buildings.

The "Anibal Pinto Block" is a five stories residential building structured on reinforced concrete slab that proyide and a total height of 13 have 8 apartments per floor. This building seismic regulation was mandatory in Chile, influenced by the traumatic experience of the $\mathrm{N}$

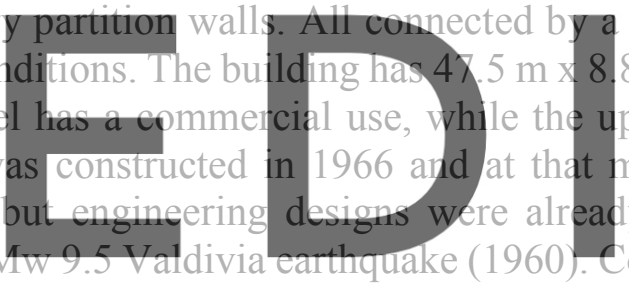
$8 \mathrm{~m}$ in plan
pper leyels
moment ho
dy styongly
constdering its age, the Anibal Pinto Block has been exposed for more than 50 years to an aggressive costal

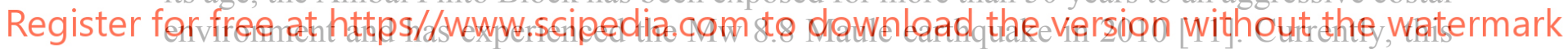
structure presents extensive damage that may imply a potential risk to community (Figure 1). Hence, a structural assessment was required to decide what action needs to be taken.

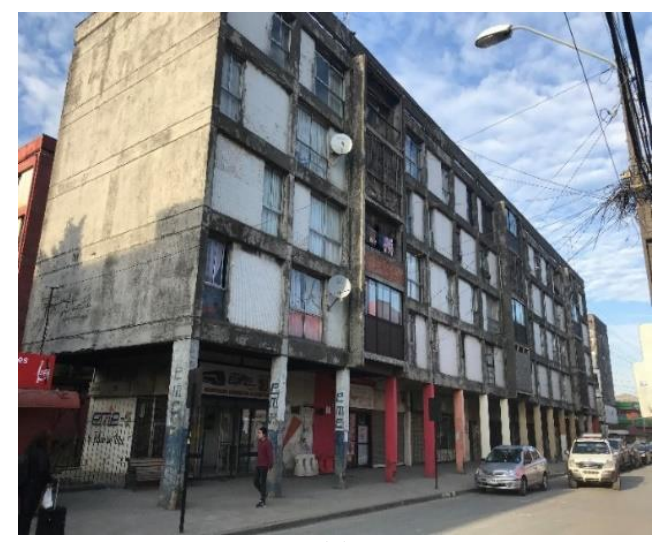

(a)

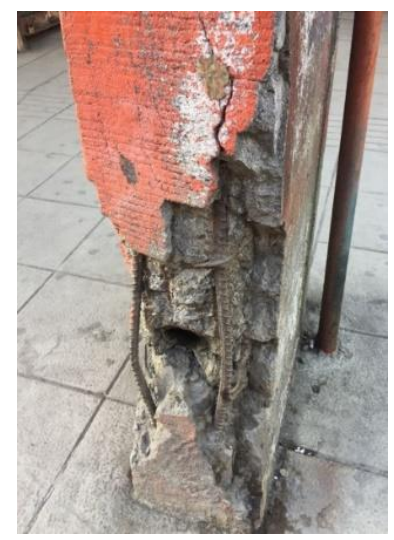

(b)

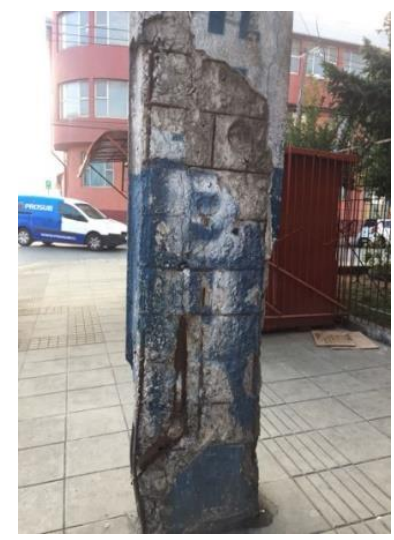

(c)

Figure 1: Anibal Pinto Block.

(a) General view, (b) damage on internal columns, and (c) damage on lateral column 


\section{METHODOLOGY}

The study presented here considers a complete damage survey, and field and laboratory tests consisting of sclerometric, carbonation, humidity and porosity measurements, in addition to concrete core extraction for compression tests. This information was used to elaborate numerical models to evaluate the seismic performance of the building under undamaged and damaged conditions.

\section{EXPERIMENTAL PROGRAM}

\subsection{Damage survey}

A survey was conducted to identify damage on reinforced concrete elements, such as, cracks, spalding, carbonation, corrosion and rebars buckling or failure [12]. This information was presented as a color diagram (Figure 2) representing damage severity according to Table 1. It can be observed in Figure 1 that the base columns suffered moderate to severe damage, being at least seven columns on a condition near to collapse. Hence, this level was considered as the critical zone.

One particular condition observed in some columns (1-3-4-6-8-9-11-13-14-16) was the inclusion of a steel pipe inside of the column core to be used a rainwater drainage (Figure 3). In most cases, these pipes have suffered severe corrosion affecting the surrounding concrete and rebars.
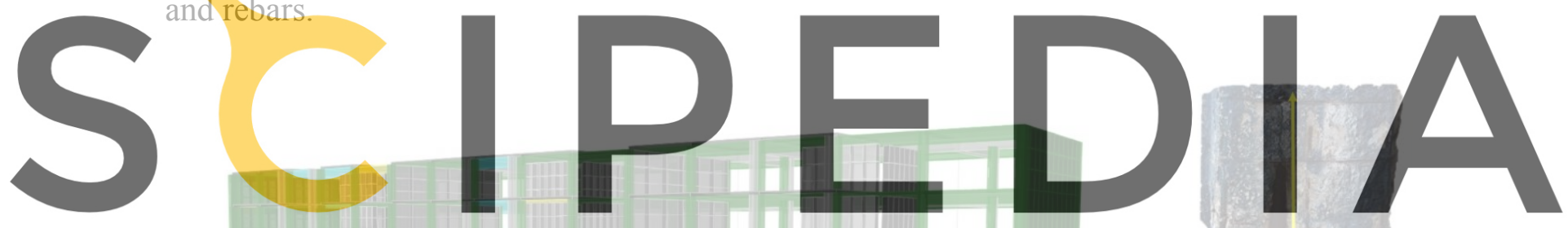

Register for free at https//www.scipedia.com to download the version without the watermark
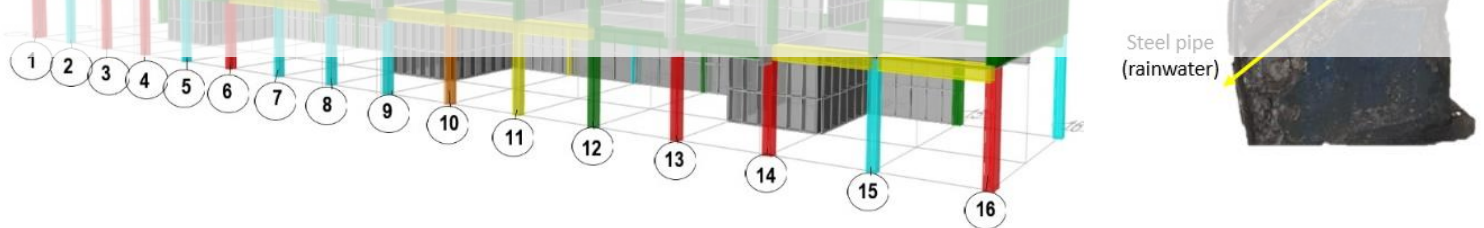

Figure 2: Damage diagram of the building

Figure 3: Steel pipe

Table 1: Damage classification

\begin{tabular}{|c|c|}
\hline Damage severity & Damage description \\
\hline None & No damage \\
\hline Moderate & Cracks and fissures \\
\hline Strong & Exposed rebars \\
\hline Severe & Rebars buckling and/or corrosion \\
\hline Near Collapse & Reduction of concrete effective area \\
\hline No information & No information \\
\hline
\end{tabular}




\subsection{Concrete carbonation}

Carbonation is the process in which the atmospheric carbon dioxide $\left(\mathrm{CO}_{2}\right)$ reacts with alkaline components of the aqueous phase of concrete, resulting in a neutralization of the entire material. Because of this, the $\mathrm{pH}$ of the concrete $(\mathrm{pH} \approx 13)$ decreases to below 10 [13]. The advance speed of the carbonation is mainly a function of the dosing, compacity, homogeneity, moisture and porosity of concrete, being the last two the most important factors $[14,15]$.

In the case of moisture, if the pores are completely dry, the $\mathrm{CO}_{2}$ will not be able to react and, if they are completely saturated, their penetration will be slow, due to the low solubility of the $\mathrm{CO}_{2}$ in the water. Only when the pores are partially filled with water (between $50 \%$ and $80 \%$ of the relative humidity) do the optimum conditions for carbonation occur [16].

In relation to porosity, the smaller capillary pores are generally always saturated with moisture, therefore, $\mathrm{CO}_{2}$ is inaccessible. On the contrary, porous concretes carbonate at higher speed.

The concrete gives protection to steel rebars by two mechanisms. On the one hand, it is a physical barrier that separates it from the environment and, on the other, the liquid enclosed in the pores of concrete is an electrolyte that can form a protective oxide in a lasting way. When the concrete is in the process of carbonation, a breakage of this protective film towards the steel occurs, giving rise to the corrosion of the reinforcements and loss of the strength of the concrete $[17,18]$. This triggers a triple consequence: (i) steel decreases its section because of corrosion, (ii) the concrete cracks due to the pressure exerted by the expansive oxide, and (iii)
reinforcement-concrete adherence decreases or disappears.
The most common method for detecting concrete carbonation is spreading the concrete
surface with an acid-base indicator solution. Usually, phenolphthalein dilyted in ethyl arcohol
and distilled water was used [19]. After applying the solution, the strface turns into d violet

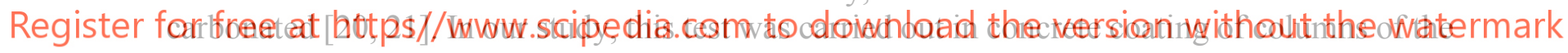
ground floor (critical area).

Together with the above, 27 concrete core samples were extracted and tested to determine the depth of the carbonation. Figure 4 shows the results of a carbonation test performed on columns in the front of the building. All the coating mortar samples extracted from the columns have carbonation, and penetration into concrete was also observed.

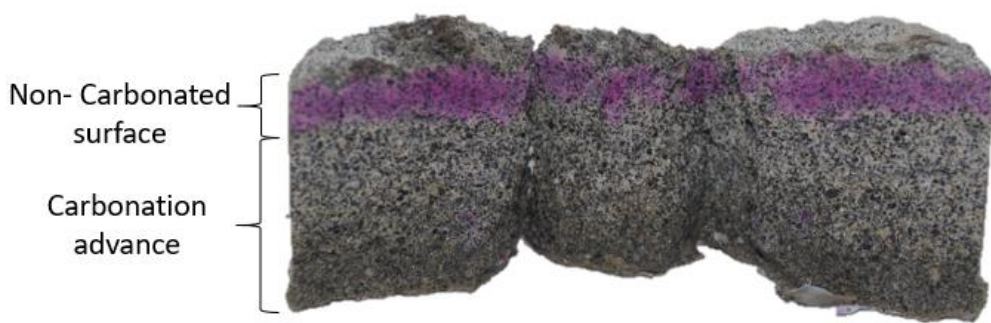

(a)

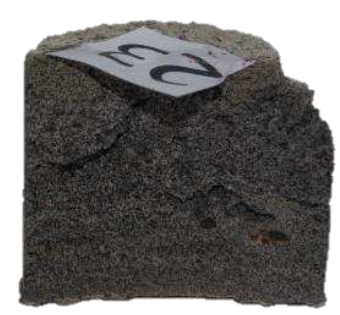

(b)

Figure 4: Test results of carbonation with phenolphthalein solution.

(a) Partially carbonated sample, and (b) Fully carbonated sample 


\subsection{Concrete porosity and humidity}

Relative humidity (RH) and porosity accessible to water (n) were determined for the critical zone. Relative humidity was measured by an infrared digital double laser thermometer (EXTECH Model 42570), while porosity was determined from the extracted samples by equation (1) according to ASTM C642-13 [22]:

$$
\eta=\frac{m_{\text {sat }}-m_{d r y}}{m_{\text {sat }}-m_{\text {sub }}}
$$

where $m_{\text {sat }}$ is the water-saturated mass of the test specimens, $m_{s u b}$ is the water-submerged mass of the test specimens, and $m_{d r y}$ is the oven-dried mass of the test specimens.

The representative porosities and humidity of the concrete in the critical zone were defined as the average value of 27 specimens (Table 2).

Table 2: Results of Porosity and Relative Humidity

\begin{tabular}{|c|c|}
\hline Representative Humidity & $64 \%$ \\
\hline Representative Porosity & $15 \%$ \\
\hline
\end{tabular}

\subsection{Steel corrosion}

Reinforcement steel bar samples were extracted from the ground level columns. Steel quality was classified as A440-280 H [23] $\left(\mathrm{f}_{\mathrm{y}}=280 \mathrm{MPa}\right.$ and $\left.\mathrm{f}_{\mathrm{u}}=440 \mathrm{MPa}\right)$ for longitudinal

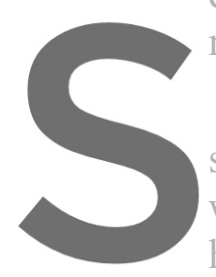
rebars and stirrups.

\section{Table 3 shows}

significant loss of cross
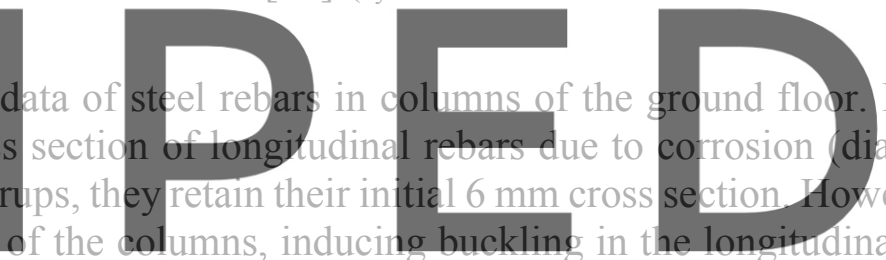

have failed at the base

spacing between stirrups corresponded to $200 \mathrm{~mm}$. It should be noted that the deterioration of

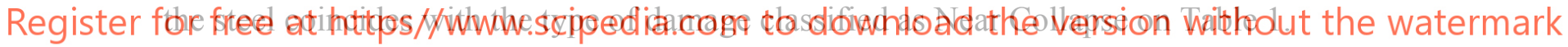

Table 3: Steels in columns

\begin{tabular}{|c|c|c|c|}
\hline Column & $\begin{array}{c}\text { Original rebar diameter } \\
(\mathrm{mm})\end{array}$ & $\begin{array}{c}\text { Corroed rebar diameter } \\
(\mathrm{mm})\end{array}$ & $\begin{array}{c}\text { cross section } \\
\text { loss }\end{array}$ \\
\hline Front & 18 & 15 & $17 \%$ \\
\cline { 2 - 4 } Columns & 25 & 25 & $0 \%$ \\
\hline \multirow{2}{*}{$\begin{array}{c}\text { Rear } \\
\text { Columns }\end{array}$} & 18 & 15 & $17 \%$ \\
\cline { 2 - 4 } & 22 & 21 & $5 \%$ \\
\hline
\end{tabular}

\subsection{Concrete characterization}

Along with the damage survey, information was collected in order to mechanically characterize the concrete. A total of 64 trials were conducted with Schmidt's hammer. (4 trials for each column of the critical area). Each of these tests consisted of 10 horizontal measurements performed following the procedure described in the NCh. 1998 Of.89 [24] and ASTM C805 [25]. On the other hand, 4 compression tests were carried out in concrete cores 
extracted from 4 columns of the critical zone. The results obtained from both tests are presented in Table 4.

Figure 5 shows a good level of linear correlation between Schmidt's hammer measurements and compression tests [26]. From these results, it was determined that the lowest resistance $(20 \mathrm{MPa})$ was observed in the critical zone (ground level columns), while the upper levels have resistances around $35 \mathrm{MPa}$.

Table 4: Results of concrete characterization tests

\begin{tabular}{|c|c|c|c|}
\hline Column & Location & Schmidt's hammer $(\mathrm{MPa})$ & Compressive Strength $(\mathrm{MPa})$ \\
\hline 5 & Front & 34 & 37,6 \\
\hline 5 & Rear & 23 & 24,6 \\
\hline 12 & Front & 39 & 41,7 \\
\hline 12 & Rear & 34 & 34 \\
\hline
\end{tabular}
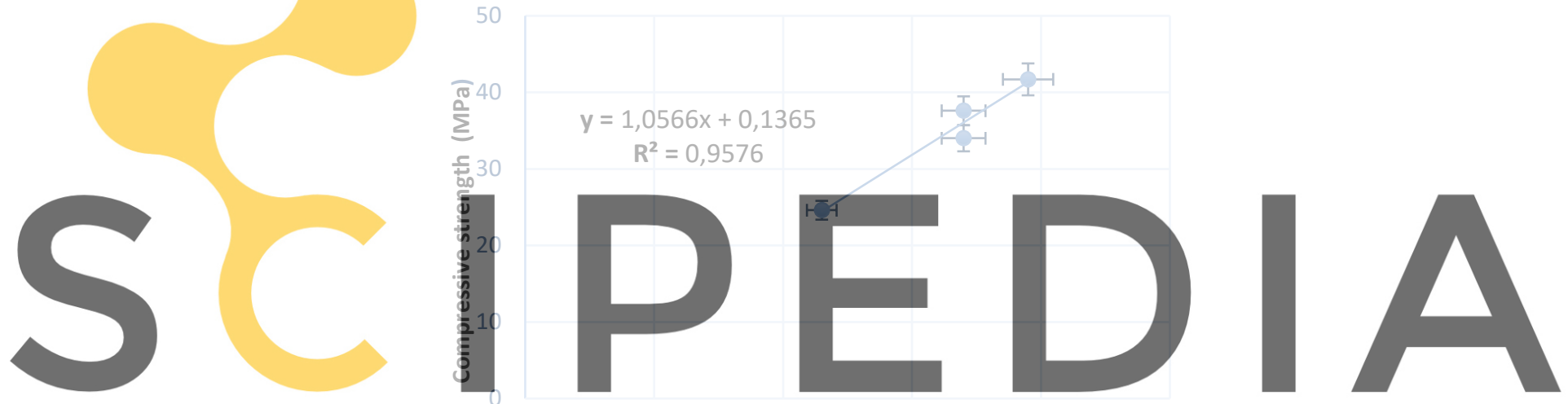

Register for free at https//www.scipedia.cosantid' downialeard) the version without the watermark

Figure 5: Correlation of results obtained from concrete strength

\section{NUMERICAL MODELS}

The information collected from original architectural drawings, on-site surveys, soil mechanics studies in the nearby area and the determination of the mechanical properties of concrete make it possible to elaborate numerical models of the building in SAP2000 (Figure 6).

Three models were considered in the analysis. One model represents the structure on its undamaged original state and the other two consider damaged conditions based on the observations made on the actual building. All models were analyzed considering the seismic loads defined by NCh433 [27] and DS61 [28] for the building site in Lota. The most relevant seismic parameters are displayed in Table 5.

In the case of the undamaged building (Model 1) a G35 concrete quality ( $\mathrm{f}^{\prime} \mathrm{c}=35 \mathrm{MPa}$ ), A440-280H steel quality ( $\left.\mathrm{f}_{\mathrm{y}}=280 \mathrm{MPa}\right)$ and handmade solid brick (mnM according to [29]) were considered. The second model (Model 2) represents general concrete degradation due to age and environmental conditions by reduction in ground floor concrete quality to G20 
$\left(\mathrm{f}_{\mathrm{c}} \mathrm{c}=20 \mathrm{MPa}\right.$ ). In the third model (Model 3), localized damage was included by eliminating the most severely damage columns.

These models were used to assess the effect of damage in the modal response of the building, but also non-linear time-history analyses were conducted to identify potential zones of damage. The time history analysis was performed applying the Concepción record of the Mw 8.82010 Maule earthquake (Figure 7), considering concentrated plasticity on beams and columns. Walls and slabs were modeled as elastic elements, because damage was not observed in those elements on the actual building. Global P- $\Delta$ effect was included in the analysis. Each analysis was conducted considering simultaneously two perpendicular components of the earthquake along the E-W and N-S directions. The plastic hinges were defined according to established in [30] and the Takeda's hysteresis model was considered.

Table 5: Seismic Parameters.

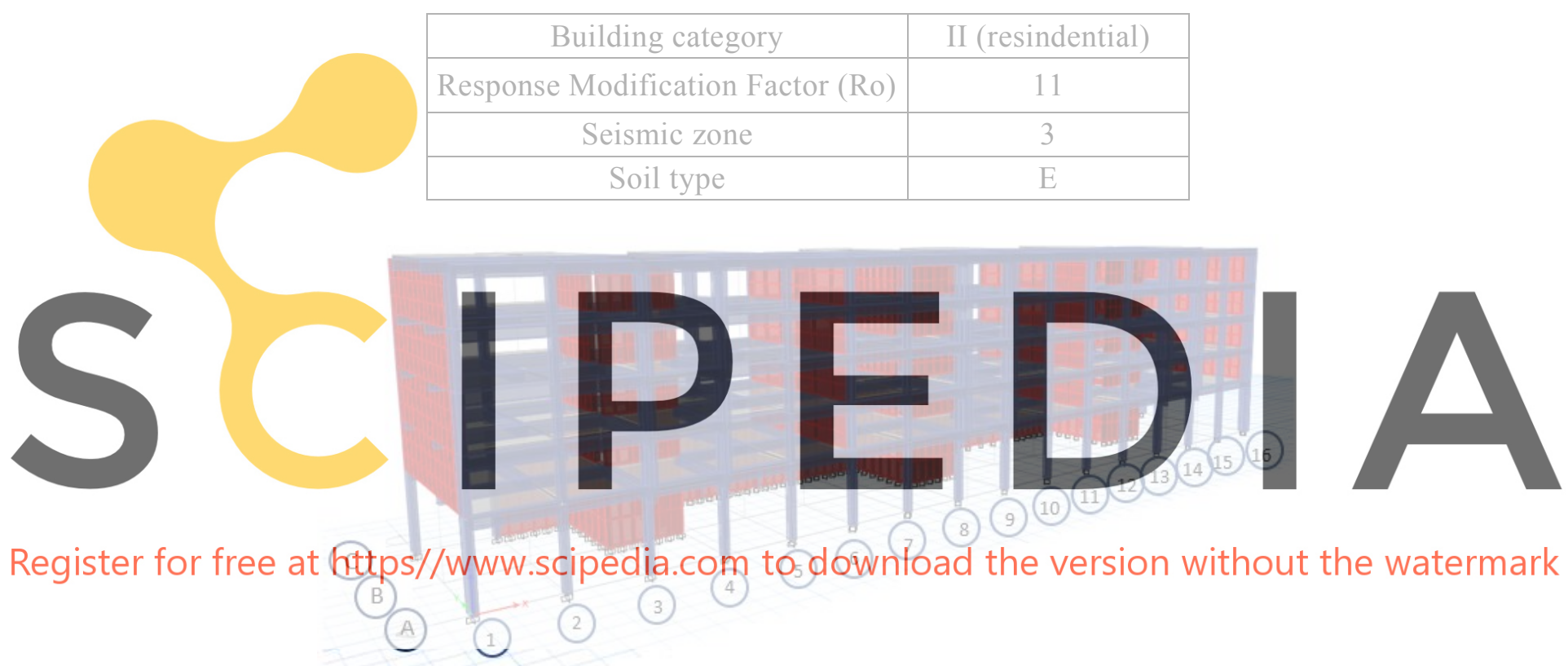

Figure 6: Building model in SAP2000

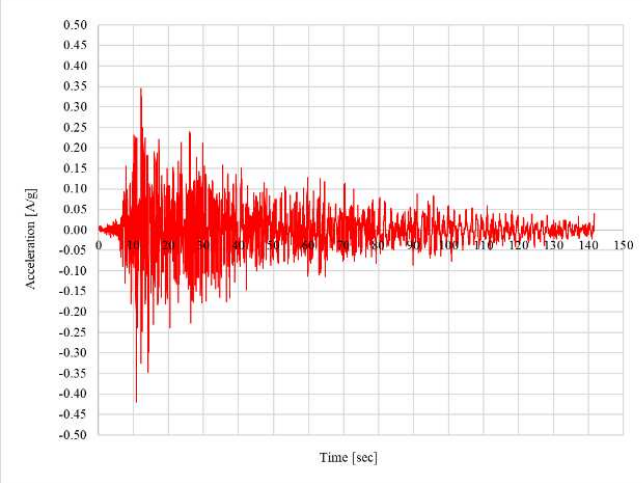

(a)

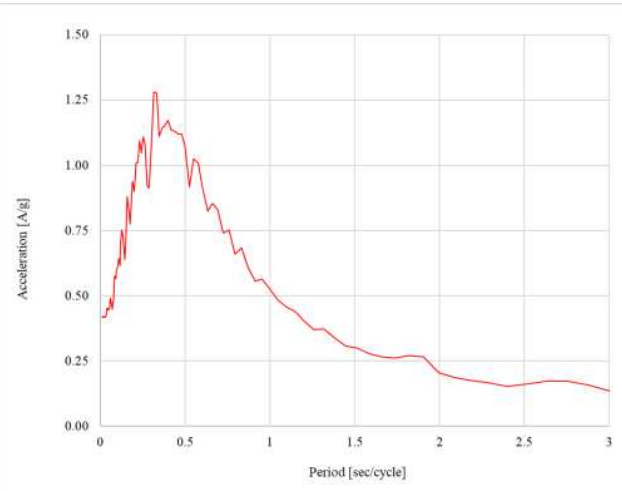

(b)

Figure 7: Concepción record of the Mw 8.8 2010 Maule earthquake.

(a) Accelerogram, and (b) Acceleration spectrum 


\section{RESULTS AND DIAGNOSIS}

\subsection{Pathologies analysis}

Figure 8 shows the relation between carbonation, porosity and percentage of crosssectional loss of steel rebars. It becomes evident that the greater is the concrete porosity, a deeper carbonation is generated. This situation facilitates corrosion in the reinforcements, with the subsequent increment in the loss of steel rebars cross section. On the other hand, Figure 9 illustrates how concrete porosity affects the material strength. Therefore, carbonation not only produced rebars corrosion, but also generates a loss of strength in the elements of the critical zone.

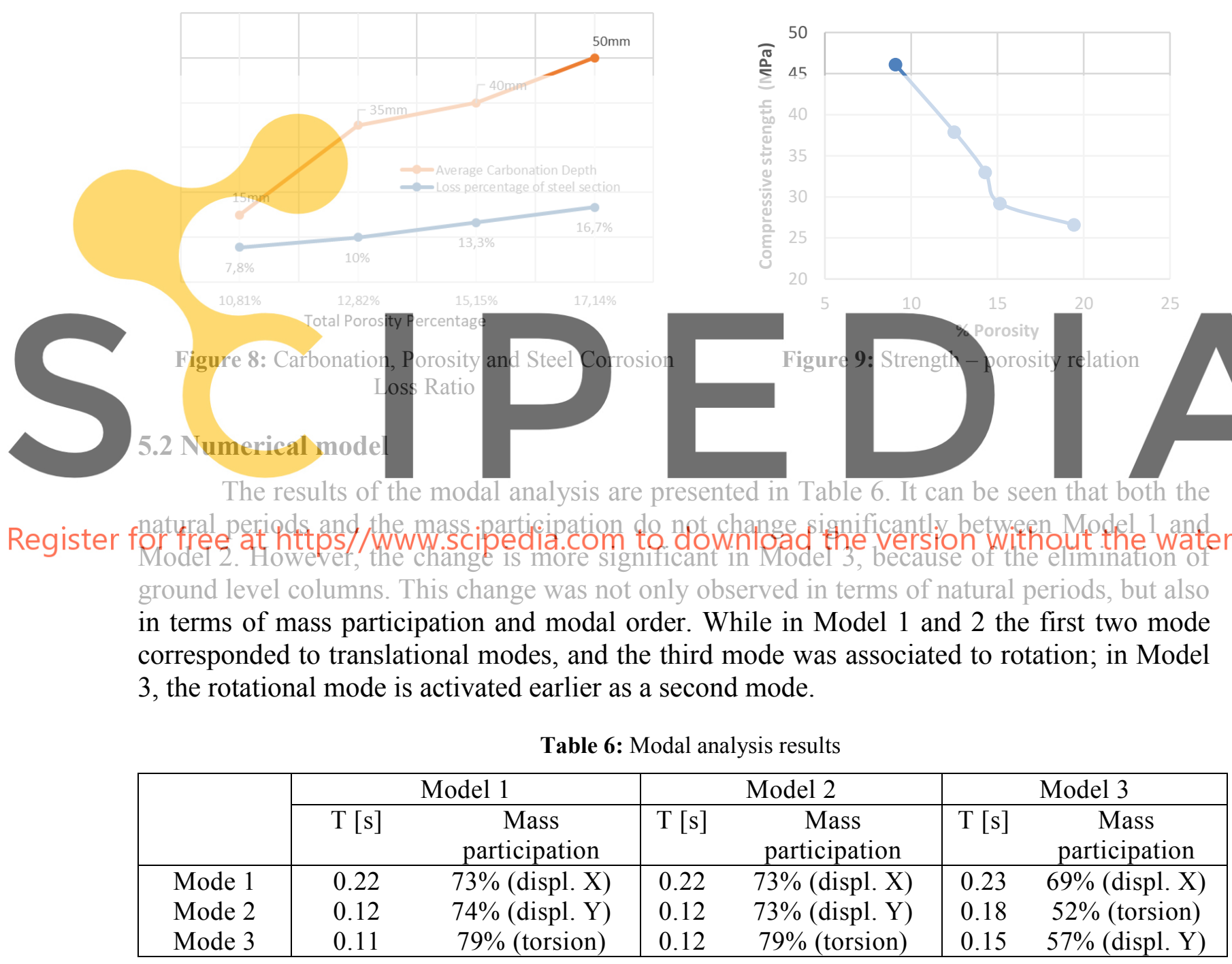

The results of the Time-History analysis are presented in Table 7 and Figure 10, where the magenta dots represent plastic hinges. It is observed that the seismic event of 2010 do not affect significantly the vertical elements (columns and walls) and most of the damage was 
concentrated in the beams. Roof displacements and interstory drift are small and within the range accepted by current Standards [27, 28], even in the case of the severely damage building (Model 3). This is explained by the secondary importance of columns to control lateral displacements, which is mostly resisted by shear walls. These stiff elements (shear walls) not only imposed strong restrictions to lateral displacements, but also produce low natural periods. These periods are below the range where most of the earthquake's energy is concentrated (only $5 \%$ of the energy affects structures with periods below $0.15 \mathrm{~s}$ ), which explains why this kind of structures were able to withstand the 2010 Maule earthquake. However, the elimination of columns in Model 3 produced an increment in the number of plastic joints in beams, because of the building rotation generated by the early activation of rotational modes. This condition sets an alert and reveals the need of retrofitting columns to prevent further damage in the structure, not only in vertical elements, but mainly in beams and slabs.

Table 7: Time-History analysis results

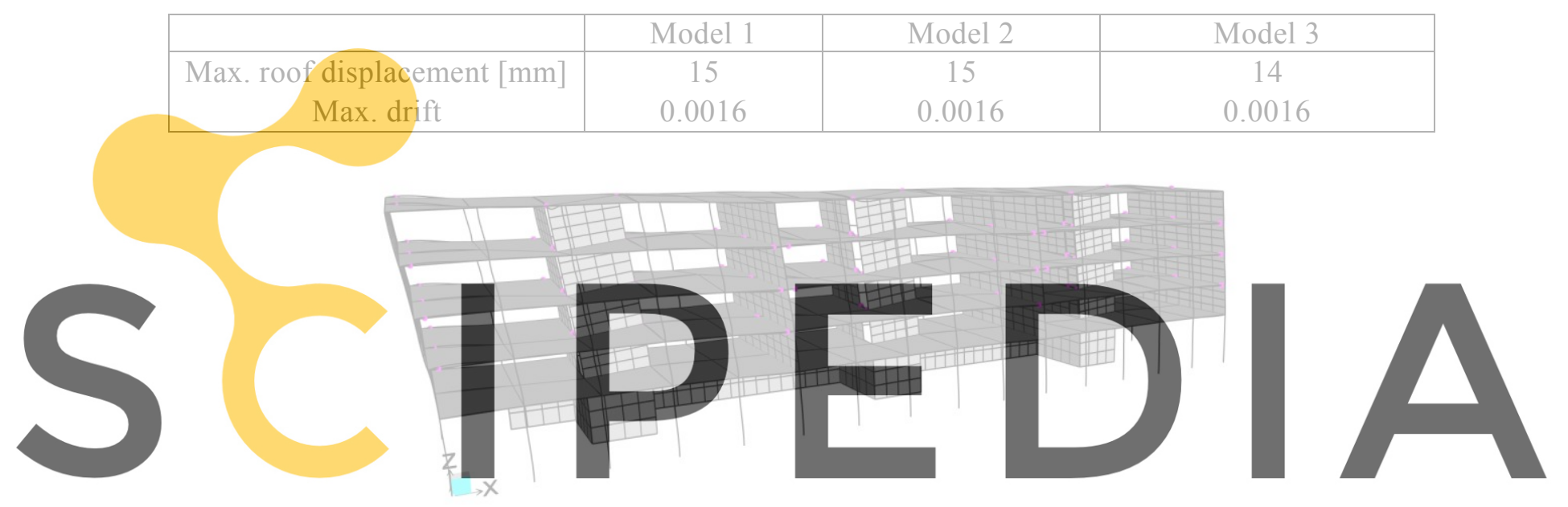

Register for free at https//www.scipedia.com toalownload the version without the watermark

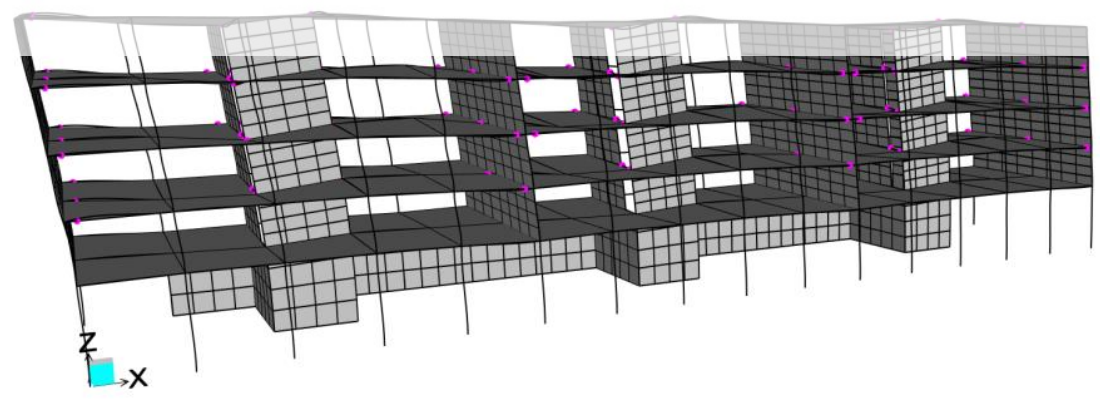

(b) 


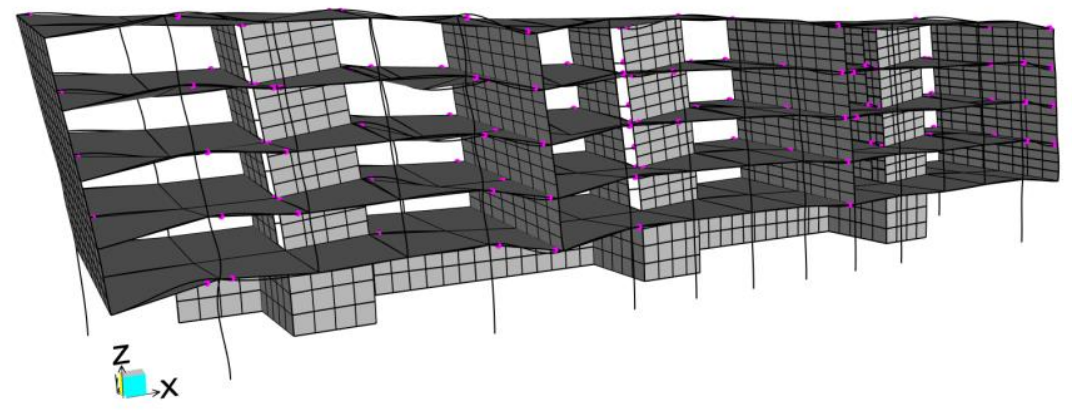

(c)

Figure 10: Plastic hinges generated on the structure.

(a) Model 1, (b) Model 2, and (c) Model 3

\section{CONCLUSIONS}

Reinforced concrete structures with significant percentages of porosity and relative humidity benefit the carbonation process. This process is even more severe when these structures are in aggressive environments, such as, coastal zones. This carbonation may produce cracks, steel rebars corrosion and a reduction in concrete strength that may compromise the structural capacity of the element.

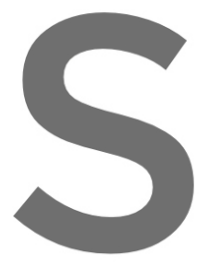
The drain pipe longitudinally embedded in the structural capacity promotes internal The seismic behavior of the building few variations in the overall results,

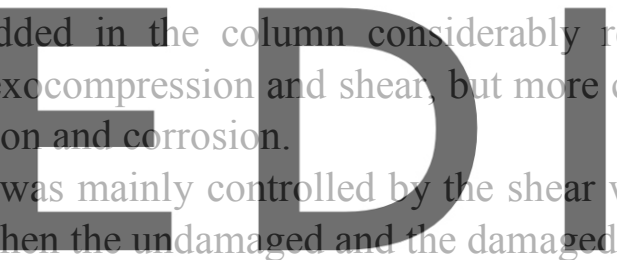
walls, with compared.

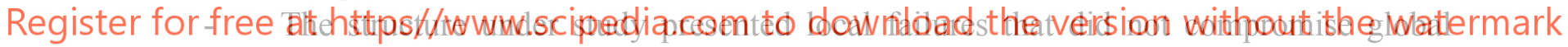
stability, especially due to the amount of shear walls of the building, which have not presented significant damage. Even tough, repaining is needed to comply serviceabinity requirements and control further structural deterioration due to rotational effects.

\section{Acknowledgements.}

The authors want to recognize the valuable contribution of Prof. Felipe Zavala and the students of the course "Concrete Technology" (2018-2) of Universidad Andres Bello that assisted in the building's damage survey. As well as the company VANROM for their collaboration during the development of the work.

\section{REFERENCES}

[1] Mark G. Stewart, Xiaoming Wang, Minh N. Nguyen. Climate change adaptation for corrosion control of concrete infrastructure. Structural Safety 35 (2012) 29-39

[2] Seung-Jun Kwon, Ha-Won Song. Analysis of carbonation behavior in concrete using neural network algorithm and carbonation modeling. Cement and Concrete Research 40 (2010) 
$119-127$

[3] I. Monteiro, F.A. Branco, J. de Brito, R. Neves. Statistical analysis of the carbonation coefficient in open air concrete structures. Construction and Building Materials 29 (2012) 263-269

[4] P.F. Marques, A. Costa. Service life of RC structures: Carbonation induced corrosion. Prescriptive vs. performance-based methodologies. Construction and Building Materials 24 (2010) 258-265

[5] Sang-Hun Han, Woo-Sun Park, Eun-Ik Yang. Evaluation of concrete durability due to carbonation in harbor concrete structures. Construction and Building Materials 48 (2013) $1045-1049$

[6] Anna V. Saetta, Renato V. Vitaliani. Experimental investigation and numerical modeling of carbonation process in reinforced concrete structures Part I: Theoretical formulation. Cement and Concrete Research 34 (2004) 571-579

[7] H. Kuosa, R.M. Ferreira, E. Holt, M. Leivo, E. Vesikari. Effect of coupled deterioration by freeze-thaw, carbonation and chlorides on concrete service life. Cement \& Concrete Composites 47 (2014) 32-40

[8]Dodge Woodson, R. (2009). Concrete Structures: Protection, Repair and Rehabilitation.Burlington, USA: Butterworth-Heinemann imprint of Elsevier.

[9] Talakokula, S. Bhalla, R.J. Ball, C.R. Bowen, G.L. Pesce, R. Kurchania, B. Bhattacharjee, A. Gupta, K. Paine. Diagnosis of carbonation induced corrosion initiation and progressionin reinforced concrete structures using piezo-impedance transducers. Sensors and Actuators A 242 (2016) 79-91

[10] Alexander Steffens, Dieter Dinkler, Hermann Ahrens. Modeling carbonation for corrosion risk prediction of concrete structures. Cement and Concrete Research 32 (2002) 935-941

[11] Astroza M., S. Ruiz and R. Astroza, 2012, Damage Assessment and Seismic Intensity Analysis of the 2010 (Mw8.8) Maule Earthquake, Submitted to Earthquake Spectra.

[12] CYTED. (2006). "4ta Edición del Manual de inspección, evaluación y diagnóstico de corrosión en estructuras de hormigón armado". Programa Iberoamericano de ciencia y tecnología para el desarrollo.

[13] Ha-Won Song, Seung-Jun Kwon. Permeability characteristics of carbonated concrete considering capillary pore structure. Cement and Concrete Research 37 (2007) 909-915

[14] M.A. Peter, A. Muntean, S.A. Meier, M. Böhm. Competition of several carbonation reactions in concrete: A parametric study. Cement and Concrete Research 38 (2008) 13851393

[15] J. Khunthongkeaw , S. Tangtermsirikul , T. Leelawat. A study on carbonation depth prediction for fly ash concrete. Construction and Building Materials 20 (2006) 744-753.

[16] W. Aperador, R. Mejía de Gutiérrez, D.M. Bastidas. Steel corrosion behaviour in carbonated alkali-activated slag concrete. Corrosion Science 51 (2009) 2027-2033

[17] In-Seok Yoon, Oguzhan C- opuroglu, Ki-Bong Park. Effect of global climatic change on carbonation progress of concrete. Atmospheric Environment 41 (2007) 7274-7285

[18] B.G. Salvoldi, H. Beushausen, M.G. Alexander. Oxygen permeability of concrete and its relation to carbonation. Construction and Building Materials 85 (2015) 30-37

[19] Cheng-Feng Chang, Jing-Wen Chen. The experimental investigation of concrete carbonation depth. Cement and Concrete Research 36 (2006) 1760- 1767

[20] UNE-EN 14630 (2007)." Determinación de la profundidad de carbonatación en un 
hormigón endurecido por el método de la fenolftaleína”. AEONOR-España.

[21] UNE 112011 (2011). "Determinación de la profundidad de carbonatación en hormigones endurecido y puestos en servicio". AEONOR-España.

[22] ASTM C642-13, 2013. Standard Test Method for Density, Absorption, and Voids in Hardened Concrete. ASTM International, West Conshohocken, PA.

[23] NCh 204 Of 2006. Aceros - Barras laminadas en caliente para hormigón armado. IINChile.

[24] NCh 1565. Of 2009: "Determinación del índice esclerometrico". INN-Chile.

[25] ASTM C805. (s.f.). Standard Test Method for Rebound Number of Hardened Concrete.

[26] NCh 1171/1. Of 2001. Hormigón - Testigos de hormigón endurecidos - Parte 1: Extracción y ensayos. IIN- Chile.

[27] NCh 433-1996 Modificada 2009. Diseño sísmico de edificios. INN Chile

[28] Ministerio de Vivienda y Urbanismo - MINVU (Chile). 2011. Reglamento que fija el diseño sísmico de edificios y deroga D.S. N¹17 MINVU of 2010.

[29] NCh. 2123-1997 Mod2003. Albañilería confinada - Requisitos de diseño y cálculo. INN Chile.

[30] ASCE/SEI. Seismic rehabilitation of existing buildings (ASCE/SEI 41-13). Reston, VA: American Society of Civil Engineers; 2013. 